\title{
A New Immunocytochemistry Method in Asterina Gibbosa (Invertebrate) after Immunizations to Trypsin
}

\author{
Michel Leclerc \\ 556 rue Isabelle Romée, 45640 Sandillon (France) \\ *Corresponding Author: Michel Leclerc, 556 rue Isabelle Romée, 45640 Sandillon (France)
}

\begin{abstract}
Injected Asterina gibbosa to HRP (Horse-radish peroxydase), to alkaline phosphatase, were labelled positively and respectively, after immunocytochemistry test in T.E.M. We discover a new immunocytochemical method by using a new antigen:the trypsin (proteolytic protein) in this same asterid: Asterina gibbosa which shows positive labelling also at the level of ergastoplasmic citernae in transmission electron microscopy, after 2 injections of trypsin. This method has not yet been used in Vertebrates. The validity of this last one is discussed.
\end{abstract}

\section{INTRODUCTION}

In recent works, we have reported positive immunocytochemical reactions to HRP (Horseradish peroxydase) in Asterina gibbosa (Asterid, Echinodermata) after injections of this enzyme ( Ref.1 ). More recently we have presented such reactions to another enzyme: the Alkalin phosphatase ( Ref.2) Results were observed in T.E.M.

In this work we try another experiment, by using a proteolytic protein : the trysin as antigen.

At our knowledge this try has not yet been performed in vertebrates.

\section{Materials ANd MethodS}

10 Asterina gibbosa were injected in the coelomic cavity with $100 \mu \mathrm{g}$ of trypsin/ animal at $\mathrm{t}=0$ day and $\mathrm{t}=8$ days as antigen. Trypsin was purchased by Worthington. Animals were kept in aquarium, in running sea water, at $10^{\circ} \mathrm{C}$. At $\mathrm{t}=13$ days, they were sacrified. Axial organs (AO) were removed, fixed at glutaraldehyd $(1,5 \%$ in cacodylate buffer), washed in cacodylate solution, and incubated in antigenic solution (Trypsin at $1 \mathrm{mg} / \mathrm{ml}$ in cacodylate buffer, $\mathrm{pH}=7,2$ ); New fixation at glutaraldehyd $(1,5 \%$ in cacodylate) was performed and followed by washing in a solution of cacodylate $(\mathrm{pH}=7,2)$. Then AO were put in a solution of Benzoyl Arginin Naphtyl Amide (5mg in $1 \mathrm{ml}$ of methanol) for 1 hour, at room temperature, solution to which was added a new solution composed of $4 \mathrm{mg}$ of Echtblausalz B dissolved in $1 \mathrm{ml}$ of distilled water for $10 \mathrm{~min}$. The new step was washing in distilled water, postfixation in $\mathrm{OsO} 4$ at $2 \%$ in distilled water, dehydratation (Alcohol $70^{\circ}$ to alcohol $100^{\circ}$ ) then embedding in Epon.

\section{CONTROLS}

10 Asterina gibbosa were injected with HRP ( Ref.1).AO were excised and fixed with glutaraldehyd (1,5\% in cacodylate buffer). Following steps are the same as those described for Trypsin experiment except $3 \mathrm{AO}$ which were prepared according the HRP method ( Ref.1)

\section{RESULTS}

Figures 66 and 67 show clearly positive labelling at the level of ergastoplasmic citernae $(\mathrm{Ce})$ and dilated « ergastoplasmic sacs » $(\mathrm{Se})$.

Structure of cells are not damaged by the use of trypsin as antigen.

Figure 65 shows exocytosis phenomenon with «antibody particles» which are on the point to be expelled (to see the arrow)

\section{DisCUSSION-CONCLUSION}

Evidence of anti-trypsin « antibodies » occur in an invertebrate : the sea star Asterina gibbosa. Furthermore we think anti-trypsin bound «antibodies» prevent the sea star cells to be damaged (Trypsin is well-known as proteolytic protein).

At our knowledge trypsin has not been used in immunocytochemical studies in vertebrates. It would be interesting to compare, in such cases, the sea star anti-trypsin and vertebrate one in T.E.M observations. 
A New Immunocytochemistry Method in Asterina Gibbosa (Invertebrate) after Immunizations to Trypsin

We learn, to day, that sea star antibody is Antibody) ( Ref.3), but how is it?. Further correlated to IPA (Invertebrate Primitive studies are necessary to elucidate this problem.

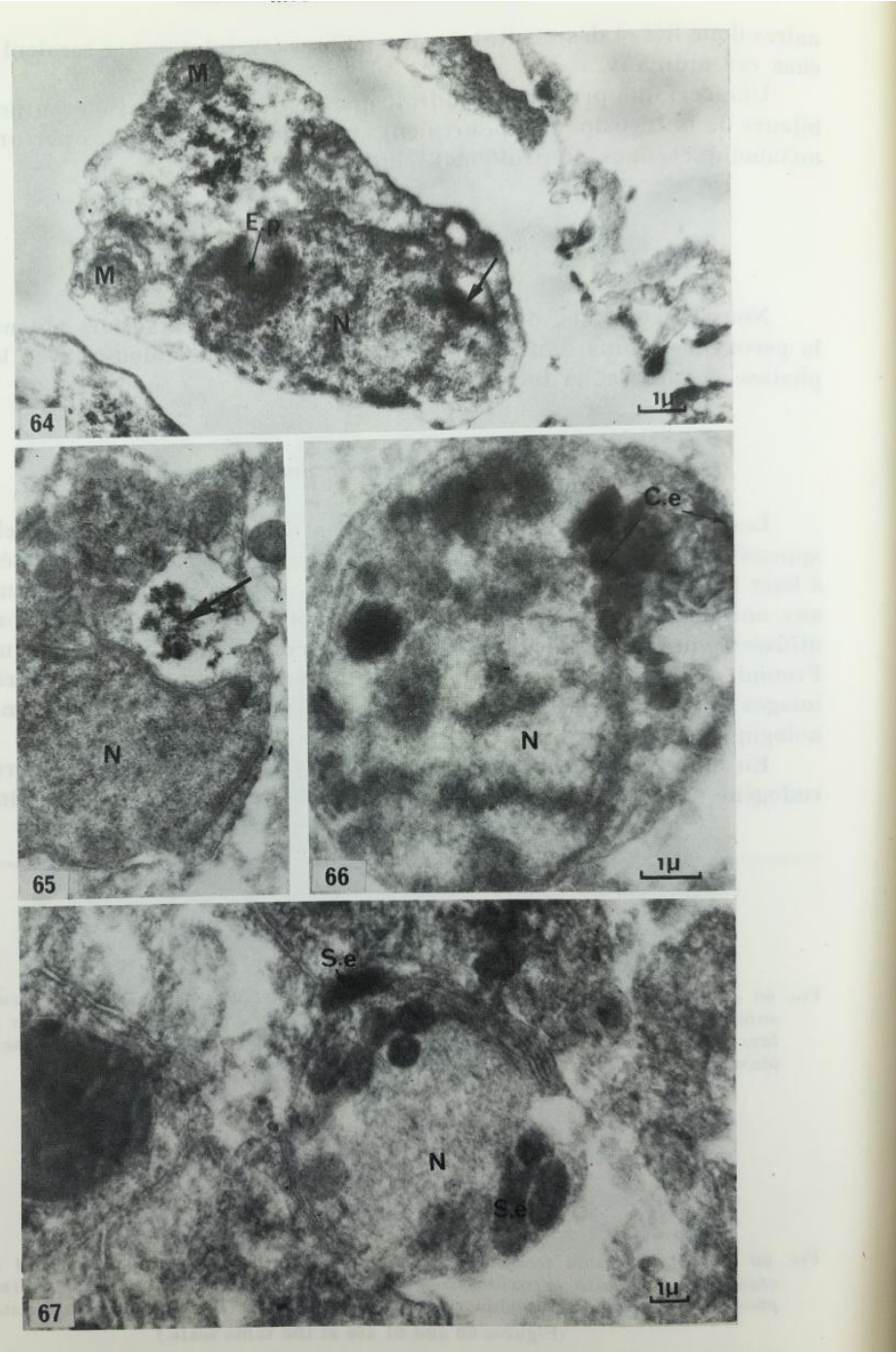

\section{REFERENCES}

[1] Leclerc, M (1973) Ann. Immunol 124C : 363-374
[2] Leclerc, M (2020) IJRSMHS to be published

[3] Leclerc, M (2013) Amer. J. Immunol: 94-95

Citation: Michel Leclerc, "A New Immunocytochemistry Method in Asterina Gibbosa (Invertebrate) after Immunizations to Trypsin", International Journal of Research Studies in Medical and Health Sciences. 2020; 5(6): 61-62.

Copyright: () 2020 Michel Leclerc, This is an open-access article distributed under the terms of the Creative Commons Attribution License, which permits unrestricted use, distribution, and reproduction in any medium, provided the original author and source are credited. 